\title{
Norethindrone Acetate
}

National Cancer Institute

\section{Source}

National Cancer Institute. Norethindrone Acetate. NCI Thesaurus. Code C702.

The orally bioavailable acetate salt of norethindrone, a synthetic progestin with some anabolic, estrogenic, and androgenic activities. As do all progestins, norethindrone binds to and activates nuclear progesterone receptors (PRs) in target tissues such as the pituitary and reproductive system; lig and-receptor complexes are translocated to the nucleus where they bind to progesterone response elements (PREs) located on target genes, followed by various transcriptional events and histone acetylation. Physiological effects include the inhibition of luteinizing hormone (LH) release, an increase in the endometrial luteal-phase, and alterations in endocervical mucus secretion. 